\title{
Overview of Electrochromic Materials and Devices: Scope and Development Prospects
}

\author{
Aleksei V. Shchegolkov*, E.N. Tugolukov, Alexandr V. Shchegolkov \\ Tambov State Technical University, 106, Sovetskaya st., Tambov, 392000, Russia \\ * Corresponding author. Tel.: +7 96223334 37.E-mail: alexxx5000@mail.ru
}

\begin{abstract}
Today, the global energy consumption associated with heating, air conditioning (cooling) and lighting of buildings (which is about $40 \%$ ) can be significantly reduced through the use of chromogenic materials or the so-called "Smart Window" technology. Approximately 20-25\% of thermal energy can be saved by reducing heat loss through the windows, and 25-30 \% of the electrical energy spent on lighting will be saved by using Smart Window technology instead of conventional windows, which are less energy-efficient in buildings.

The article provides an overview of electrochromic materials and the practice of their use in various optical devices, as well as methods for their preparation. The prospects of using various electrochromic materials as coatings for window glasses, mirrors, and large-area displays are considered. A modern analysis of electrochromic devices based on nanostructured materials used in various applications is presented. The latest achievements and developments in the field of electrochromic materials are discussed. The paper discusses the findings of studies and the possibilities of their use for protection from light radiation, in particular, their use as light filters and light modulators for optoelectronic devices are ed.
\end{abstract}

\section{Keywords}

Electrochromism; electrochromic devices; smart windows; transition metal oxides; viologens.

(C) Aleksei V. Shchegolkov, E.N. Tugolukov, Alexandr V. Shchegolkov, 2020

\section{Introduction}

In the last decade, increasingly growing interest in solar energy has led to the development of new technologies for the conversion, control and storage of energy from this inexhaustible source. The advantages of these technologies are obvious, but the most attractive feature is associated with reduced environmental impact. In addition, a big amount of economic resources have been spent on the development of the automotive, aerospace, military, and household sectors. A new class of optical active materials has become a subject of great interest, especially materials that allow controlling the change in light absorption. Thus, savings can be achieved due to lower energy consumption for air conditioning in the summer, as well as for heating in the winter. Moreover, this technology is able to provide resource saving, which is an urgent problem throughout the world. Monitoring of visible radiation (to save lighting energy) and the control of infrared radiation (to save cooling and heating energy) can be achieved by using electrochromic materials (which can reduce energy consumption by an average of more than $30 \%$ compared to conventional glazing). Also, the use of electrochromic glasses reduces heat loss, and in some cases replaces air conditioners, the loss of freon of which is today the main reason for the growth of ozone holes in the atmosphere.

\section{Chromogenic Materials}

There is a class of "smart materials", known as chromogenic, that allow controlling reflected or scattered light passing through them as a result of external influences of a different nature [1], such materials have various optical applications [2, 3]. According to the law of conservation of energy, also known as the Kirchhoff law, which is presented in the form of equation (1), solar radiation incident on the 


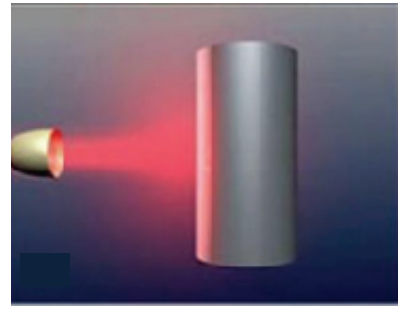

a)

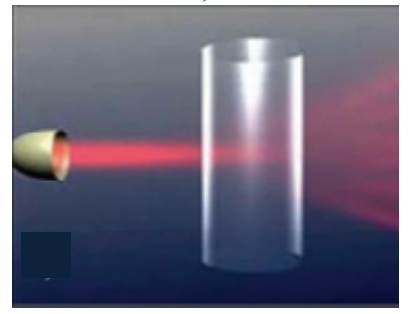

c)

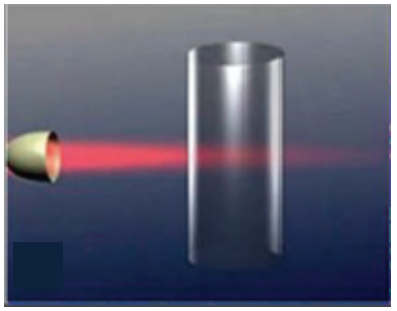

b)

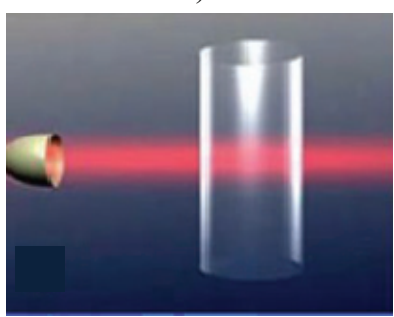

d)
Fig. 1. Possible interaction of light radiation with an optical object:

$a$-reflection; $b$-absorption; $c$ - scattering; $d$ - transmission

surface of a material object (Fig. 1) can be reflected $(\mathrm{R})$, scattered (S), absorbed (A) or transmitted (T):

$$
\mathrm{R}+\mathrm{A}+\mathrm{S}+\mathrm{T}=1 .
$$

Chromogenic materials are able to control any of these four parameters using physical processes of varied nature (heating and cooling, voltage, light exposure).

Depending on the nature of the external effect on the chromogenic material, the following group is distinguished: materials that change their color under the influence of light - photochromic (PhC); electrical voltage - electrochromic (EC); temperature thermochromic (ThC); gas - gaschromic (GhC), as well as liquid crystals (PDLC \& LCD nematics) when exposed to electrical voltage [4]. From this group, EMs are attracting increasing interest of researchers in connection with the possibility of creating on their basis a number of devices for optoelectronics: information display elements, "Smart Window", light shutters, intelligent mirrors [5-7]. An unprecedented interest in EM is associated primarily with the use of nanostructured materials [8-10] as EM or as modifying materials, as well as with the technical improvement of diagnostics and analysis of chemical composition and structure (SEM, PEM, TEM, XPS analysis, etc.) obtained by EM based on various electrochromic compounds.

The advantage of EC-based technology for building glazing introduced by Madison Gas and Electric is shown in Fig. 2. This figure compares three chromogenic technologies based on $\mathrm{PhC}$, ThC and $\mathrm{EC}$ aimed at reducing the energy consumption of buildings by reducing the energy consumption for lighting, air conditioning and heating $[4,11]$. Technologies based on $\mathrm{PhC}$ and $\mathrm{ThC}$ are effective in terms of lighting and thermal insulation, respectively, the use of $\mathrm{EC}$ technology $[7,12]$ allows for the optimal combination of lighting level and room temperature due to the largest number of glass dimming modes controlled remotely by electrical signals.

Electrochromic technologies involve the use of transparent conductive coatings or a transparent electrode (the ITO electrode $\left(\operatorname{In}_{2} \mathrm{O}_{3}: \mathrm{Sn}\right)$ is more common and the FTO $\left(\mathrm{SnO}_{2}: \mathrm{F}\right)$ electrode is less common) required for electrical control of information output devices (displays), a Smart Window, or IR reflective coating to dissipate thermal energy-saving windows [13].

The main problem of using ITO-coating for EC-technologies is the limited resources for their production, which significantly increases the cost of this technology. According to modern estimates, the reserves of indium, which is the main element of the ITO transparent electrode, will be exhausted in the next 20 years [14], which is associated with a significant increase in the use of ITO for smartphones [15]. Since 2009, the Smart-window market has been expanding due to an increase in the popularity and demand for glasses with adjustable transparency [16].

An alternative to ITO and FTO is polymers and nanomaterials. Organic polymers (poly $(3,4-$ ethylenedioxythiophene) or PEDOT have several advantages over ITO, such as flexibility, ease of printing and low cost. A thin layer of carbon nanotubes (CNTs) is also a promising option because of their high

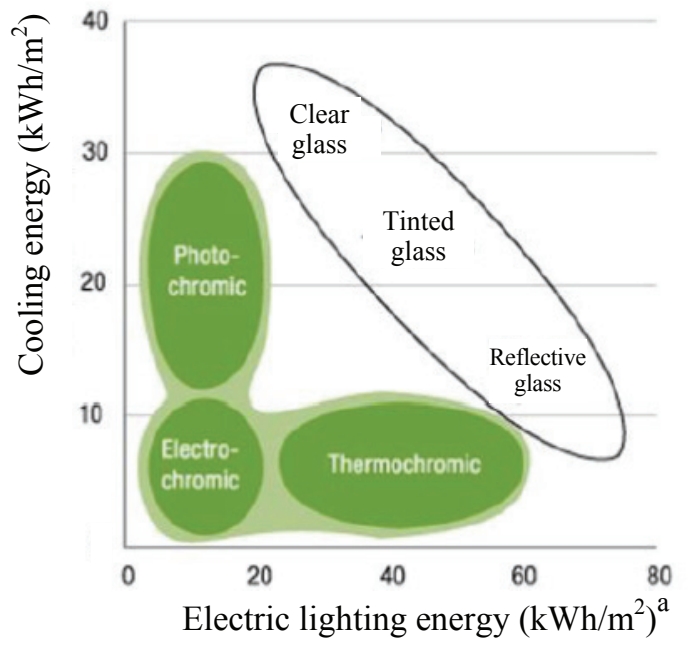

Fig. 2. Electric lighting energy and cooling energy for different types of fenestration.

From Ref. [11]: a. Lighting savings the use of a switched or dimmable electric lighting control 
electrical conductivity. Electrodes based on graphene [17] and its modifications also have a high degree of electrical conductivity [18] and light transmission coefficient [19]. Carbon nanomaterials are widely used in a number of EC devices $[9,10,20]$.

\section{Electrochromism}

In the late 1960s, the scientist S.K. Deb [21] first discovered and investigated a phenomenon called electrochromism. A new phenomenon arose at the junction of the two sciences of physics and chemistry. As a result of his experiments, S.K. Deb described a new electrophotographic system, which consists of a thin film of transition metal oxide and a thin film photoconductive layer located between a pair of electrodes. When an electric field is applied to this composite structure, an optical image is projected onto it and the resulting modulation of the conductivity pattern in the photoconductive layer causes a similar color pattern in the oxide layer, thereby forming a visible image [22].

Since the mid-1970s, electrochromism has been defined as a physical phenomenon in materials associated with a reversible change in light transmission or color under the influence of an electric field or current [23]. This phenomenon applies not only to visible color changes, but also for the near infrared region, i.e. in the infrared and thermal ranges. In [24], the main direction of application of the electrochromic effect is the development of indicators (displays), which should replace LED and liquid crystal displays.

Svensson J.S.E.M. and Granqvist C.G. developed a more detailed theory of the optical properties of crystalline electrochromic materials based on the scattering of free electrons in heavily doped semiconductors with ionized impurities [25]. At the moment, there are still some contradictions regarding the staining mechanism in amorphous $\mathrm{WO}_{3}$ films. It is widely believed that optical modulation in films is directly related to the double injection / extraction of electrons and ions in the films, as shown by the following reaction [26, 27].

$$
x \mathrm{M}^{+}+x e^{-}+\mathrm{WO}_{3}=\mathrm{M}_{x} \mathrm{WO}_{3},
$$

where $\mathrm{M}^{+}=\mathrm{H}^{+}, \mathrm{Li}^{+}$, etc. This process increases the amount of ions $\mathrm{W}^{5+}$ and, hence the number of color centers.

Schirmer O.F. [28] assumed that the optical absorption of films is due to small polarons (SP) transitions between two nonequivalent tungsten centers $\left(\mathrm{W}^{5+}\right.$ и $\left.\mathrm{W}^{6+}\right)$ :

$$
h v+\mathrm{W}^{5+}(\mathrm{A})+\mathrm{W}^{6+}(\mathrm{B}) \rightarrow \mathrm{W}^{5+}(\mathrm{B})+\mathrm{W}^{6+}(\mathrm{A}) .
$$

According to equation (3), the inserted electrons are localized in the nodes $\mathrm{W}^{5+}$ and polarize the surrounding lattice, forming small polarons. Falling photons are absorbed by these small polarons, which jump from one place to another. Proposed Intervalent Transition Model Faughnan B.W. and Crandall R.S. has a similar physical explanation for this process. Although these models are consistent with many experimental observations, they cannot fully explain the mechanism of electrochromism.

The commercial interest in electrochromism is mainly focused on windows, mirrors, and displays. EC devices (ECDs) consist of a two-electrode electrochemical cell in which at least one optically transparent electrode is used [26, 27]. To achieve a noticeable change in the optical state, a specific charge $\left(\mathrm{mK} / \mathrm{cm}^{2}\right)$ is required, in order to reduce power consumption to the level of LCD displays and light modulators, ECDs must use ECs with very high staining efficiency [29].

\section{Electrochromic Compounds (materials)}

Among the EC (Table 1), which have the effect of electrochromism, one can find transition metal oxides (TMT), Prussian blue (PB) systems, viologens, conducting polymers and rare-earth metals. Electrochromic materials (EC) can be found in some biological materials showing this phenomenon $[30,31]$.

Inorganic materials represent a large proportion of electrochromic materials, most often they are transition metal oxides: cerium, chromium, cobalt, copper, iridium, iron, manganese, molybdenum, nickel, niobium, palladium, praseodymium, rhodium, ruthenium, tantalum, titanium, tungsten and vanadium [26]. Among them, the oxides of iridium, molybdenum, nickel, titanium, and tungsten exhibit high specific indices [27], the light transmission of which varies from a transparent (oxidized) state to a colored (reduced) state by electrochemical reduction (cathode materials), while the compounds change from transparent ( reduced) to a colored (oxidized) state are called anodic electrochromic compounds (Fig. 3).

Electrochromic properties are observed in a number of organic compounds, such as viologens, conductive polymers, metal polymers and metallophthalocyanines, which possess high electrochromic properties [33] (Fig. 4). For example, conjugated pyridine derivatives, which primarily include viologens, have high cyclicity, low values of working potentials and other valuable properties [34]. 
Examples and applications of well-known EC [32]

\begin{tabular}{|c|c|c|}
\hline EC class & Name & Purpose \\
\hline $\begin{array}{l}\text { Transition Metal Oxides } \\
\text { (TMOs) }\end{array}$ & $\mathrm{WO}_{3}, \mathrm{MoO}_{3}, \mathrm{~V}_{2} \mathrm{O}_{5}, \mathrm{TiO}_{2} \mathrm{Nb}_{2} \mathrm{O}_{5}, \operatorname{Ir}(\mathrm{OH})_{3}, \mathrm{NiO}$ & $\begin{array}{l}\text { Smart Window, mirrors, } \\
\text { sensors }\end{array}$ \\
\hline Prussian Blue (PB) System & $\begin{array}{l}\text { Prussian blue }\left(\mathrm{C}_{18} \mathrm{Fe}_{7} \mathrm{~N}_{18}\right) \text {, } \\
\text { Prussian brown }\left(\mathrm{C}_{6} \mathrm{Fe}_{2} \mathrm{~N}_{6}\right) \\
\text { Prussian green }\left(\mathrm{C}_{3} \mathrm{FeN}_{3}\right) \\
\text { Prussian white }\left(\mathrm{C}_{6} \mathrm{Fe}_{3} \mathrm{~N}_{6}\right)\end{array}$ & Smart Window, display \\
\hline Conductive polymers & $\begin{array}{l}\text { PEDOT (being EDOT }=\mathrm{C}_{6} \mathrm{H}_{6} \mathrm{O}_{2} \mathrm{~S} \text { ), } \\
\text { PPy (being Py }=\text { Pirrole }=\mathrm{C}_{4} \mathrm{H}_{5} \mathrm{~N} \text { ), } \\
\text { PT (being = thiophene }=\mathrm{C}_{4} \mathrm{H}_{4} \mathrm{~S} \text { ) } \\
\text { PANI (being anyline }=\mathrm{ANI}=\mathrm{C}_{6} \mathrm{H}_{4} \mathrm{~S} \text { ), }\end{array}$ & Smart Window, display \\
\hline Viologens & derivatives of 3-aryl-4,5-bis(pyridine-4-yl)oxazole & $\begin{array}{l}\text { Car rear view mirrors } \\
\text { and displays }\end{array}$ \\
\hline $\begin{array}{l}\text { Transition metals } \\
\text { and lanthanides }\end{array}$ & $\begin{array}{l}\mathrm{Y} \text {, 'symmetric GdMg', }\left[\mathrm{Ru}^{\mathrm{II}}(\mathrm{vbpy})_{3}\right]^{2+}(\text { being vby }=4 \text {-vinyl-4'- } \\
\left.\text { methyl-2,2'-bipyridine, vinyl }=-\mathrm{CH}=\mathrm{CH}_{2}\right) \\
\text { и poly- }\left[\mathrm{Ru}^{\mathrm{II}}(\text { vbpy })_{2}(\text { py })_{2}\right] \mathrm{Cl}_{2}\left(\text { being py }=\text { pyridine }=\mathrm{C}_{5} \mathrm{H}_{5} \mathrm{~N}\right)\end{array}$ & Intelligent Mirrors \\
\hline Metallophthalocyanines (Pc) & {$\left[\mathrm{Lu}(\mathrm{Pc})_{2}\right]$ being $\mathrm{Pc}=\mathrm{C}_{32} \mathrm{H}_{18} \mathrm{~N}_{8}$} & Display \\
\hline
\end{tabular}

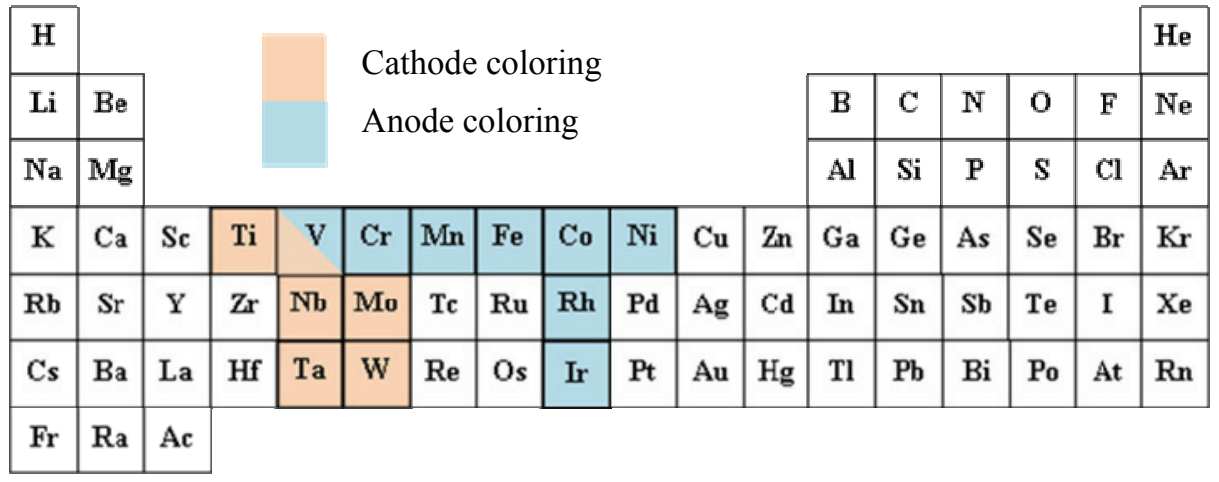

Fig. 3. Electrochromic oxides with cathodic and anodic coloring [26]<smiles>[R][n+]1ccc(-c2cc[n+]([R])cc2)cc1</smiles><smiles>[Y]N1C=CC(c2cc[n+]([Y])cc2)C=C1</smiles><smiles>C1CC1C1CC1</smiles><smiles>[Y]N1C=CC(=C2C=CN([Y])C=C2)C=C1</smiles>

Fig. 4. Three common redox states of viologen [31]
The synthesis of new organic compounds, as well as the preparation of EC based on inorganic compounds with high productivity and multifunctionality, are areas of active study all over the world [35-37].

\section{Electrochromic Devices (ECD)}

There are four main technologies of "Smart Window" with electric control based on different operating principles $[3,4]$, which are presented in Fig. 5.

PDLC and LCD: glass is made on the basis of a liquid mixture of polymer crystals located among two glass layers with an electrically conductive coating and forming a layer of variable transparency.

SPD uses "suspended particles" that are placed between two layers of an electrically conductive 


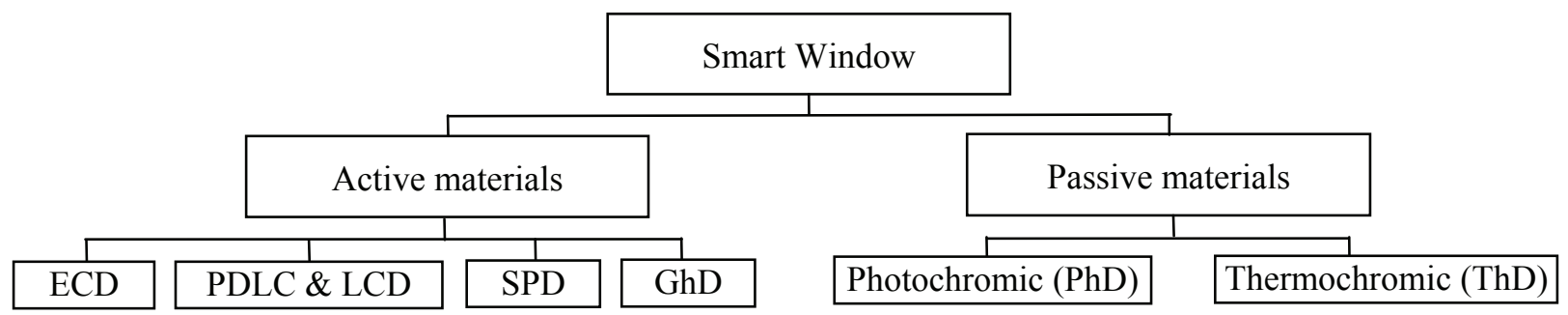

Fig. 5. Classification "Smart Window" [38]:

ECD - electrochromic devices; PDLC \& LCD - glass made on the basis of a liquid mixture of polymer crystals; $\mathrm{SPD}$ - suspended particles placed between two electrically conductive coatings; GhD - gas chrome devices

coating. The SPD film is almost similar in structure to the LCD. But thanks to a layered rod-like particle structure, SPD glass smart panels are visually open in different states.

Glassiled: LED technology that offers ample opportunities for variations in the design, color and light intensity of LEDs.

The use of these technologies not only as display elements, but also as energy-saving to reduce heating, air-conditioning and lighting costs by saving energy that can be achieved in buildings and vehicles, i.e. places where modern people spend about $90 \%$ of their time.

These variable transmission technologies allow optical switching from a transparent or discolored state to a color, darkened, or translucent state due to chromogenic materials. In all cases, these technologies require the use of transparent conductors of electric current.

ECDs usually consist of multilayer structures with transparent conductors, electrochromic films, ionic conductors, and ion storage films. ECD's for architectural applications include thin EC films

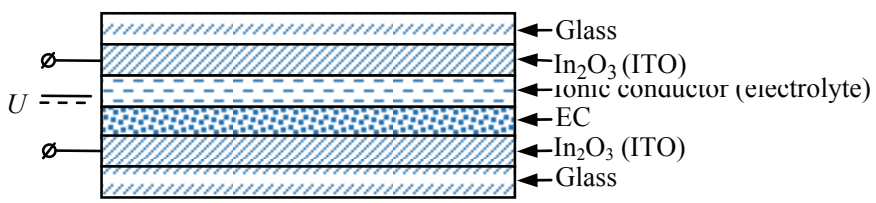

Fig. 6. Flowchart of ECD

(obtained by different methods), which are placed between two glass panels, as shown in Fig. 6 .

The staining of thin anode films occurs due to electrochemical oxidation and, in the case of cathode materials, due to electrochemical reduction, including the transfer of ions from EC films, which involves the use of an additional coating for storage and transport of ions. The "Smart Windows" technology is represented by various companies and is available on the market as energy-saving [12]. Depending on the purpose of the ECD - devices can be assembled with materials of different nature; Fig 7 shows the classification of materials and technologies needed to create an ECD.

ECD-based technologies are finding more and more application along with PDLC and LCD and occupy their place in the "Smart Window" market.

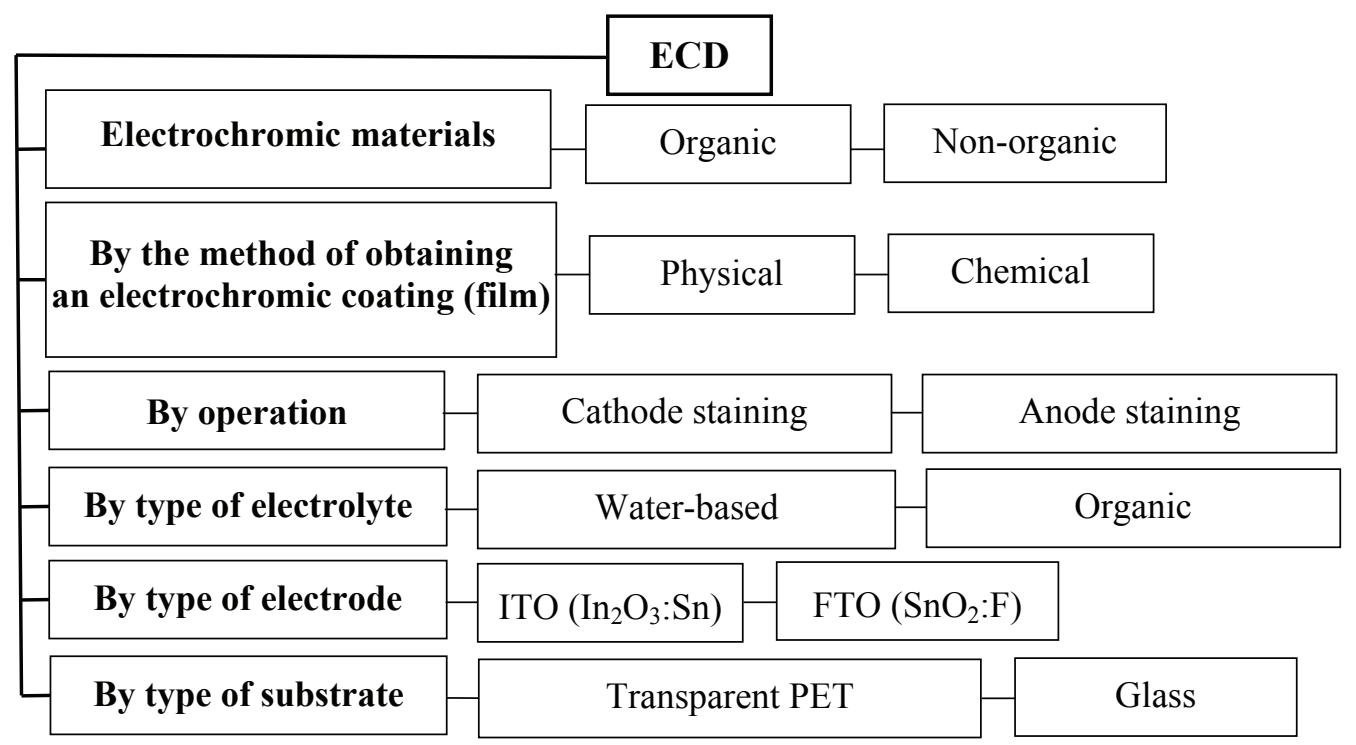

Fig. 7. ECD classification 


\section{ECD prospects}

ECD's technologies are increasingly used, i.e. are becoming more commercialized. For example, Gentex Corporation [39] has developed a system for reflecting from a driver's side or rear view mirror using automatic dimming control at night, which eliminates glare from the rear view mirror due to EC light absorption. In the decolorized state, the ECD acts like a normal mirror, in the case of light entering the surface of the EC, moderate dimming is ensured, while maintaining the function of the mirror (Fig. 8). For the operation of this device, two light sensors are used, one of which works to detect an artificial light source, and the second to detect daylight and turn off the first sensors. Over a million of these mirrors have been purchased to date. As a "Smart Window", EC mirrors do not require a quick response.

ChromoGenics (Sweden) developed an ECD (Fig. 9), representing a prototype of an electrochromic window $\left(0.8 \times 1.8 \mathrm{~m}^{2}\right)$, in a darkened state changing its color to gray, response time after 750 cycles of 40 and 120 seconds for staining time and bleaching, respectively, the light transmission range from $70 \%$ in a transparent state to $37 \%$ in a colored state (after 1400 cycles it becomes about $41 \%$ ).

In the laboratory of Gesimat GmbH (Germany, Berlin), a "Smart Window" was developed that allows you to create six different staining states, depending on the level of illumination of the object (Fig. 10). ECD has a Li-Ion conductive electrolyte, essentially used as a battery between two transparent electrodes. Depending on the state of the ECD, the Li-Ion battery circuit may be closed or open [40].

More and more modern buildings with low energy consumption (Fig. 11, 12) are equipped with ECD's and PDLC with a "Smart Window" switchable solar glass. The main manufacturers of Smart Windows are companies such as ChromoGenics (Sweden), EControlGlass (Germany), Kinestral Technologies, Inc. (USA), SageGlass (USA) and View Inc. (USA).

But for the wider adoption of ECD's, there are some issues that need to be addressed and turn ECD into an affordable technology. These improvements include, for example, ECD switching speeds, contrast ratio, transparency level and finally the cost per $\mathrm{m}^{2}$.

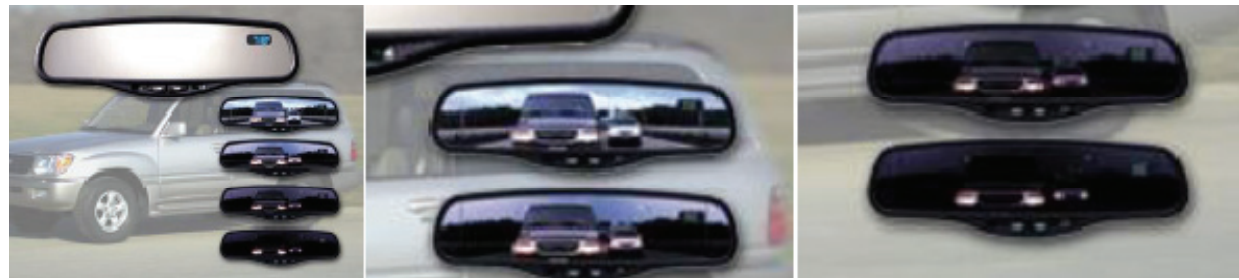

Fig. 8. EC mirror (Gentex Corporation)

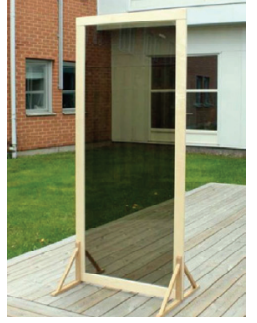

Fig. 9. ChromoGenics Smart Window Prototype
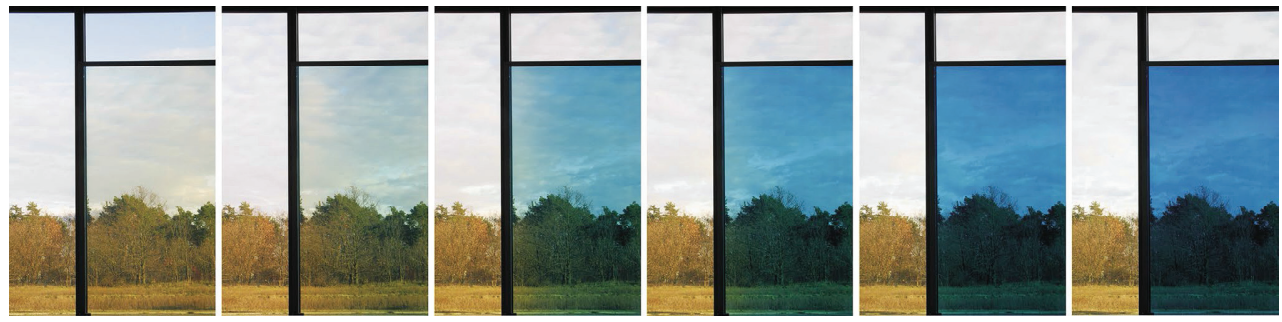

Fig. 10. Six different tint states of the Smart Window based on tungsten oxide and Prussian blue as electrochromic layers and PVB ion-conducting polymer electrolyte
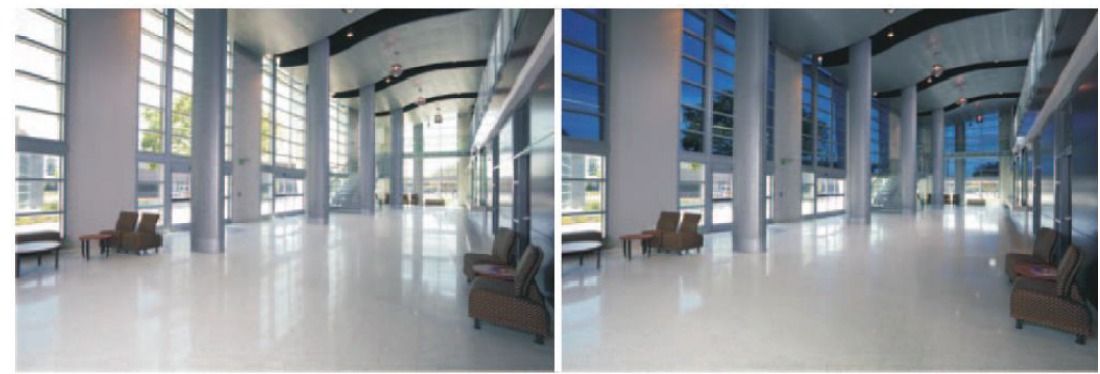

Fig. 11. Electrochromic Windows at Chabot College Community College, California (Source: International Energy Agency (IEA) (2013)) 

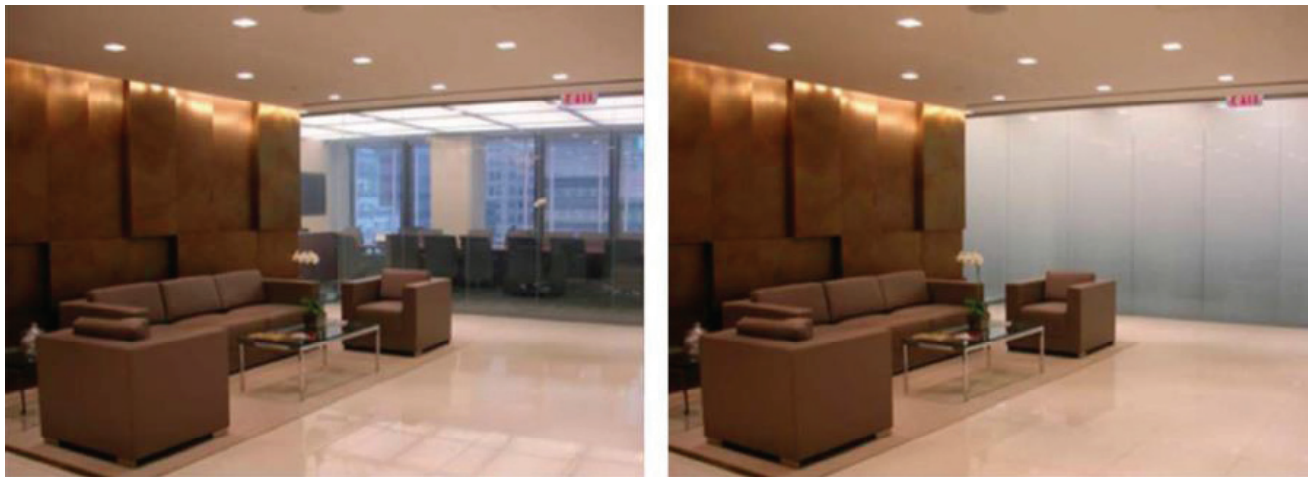

Fig. 12. PDLC operating modes: transparent mode and dark mode, respectively (Source: Rezaei, 2017)

\section{Conclusion}

Today, further development of the energysaving and energy-efficient technology sector around the world is impossible without chromogenic materials, in particular, the EC. ECDs are increasingly used in various technologies and applications, and are commercially attractive due to a number of significant advantages of using as a "Smart Window" in contrast to other chromogenic devices presented in this article: PDLC \& LCD, SPD, $\mathrm{GhD}$, ThD and PhD. However, their mass distribution is hindered by the relatively high cost of manufacturing ECD associated primarily with the energy-consuming technologies for producing some components of the ECD, in particular the EC.

Thanks to the development of modern technologies and materials, as well as the intensive research of EC by world companies and scientific laboratories, consumer (technical and economic) indicators are significantly improved, which indicates a high potential for EDC in the foreseeable future.

\section{References}

1. Bamfield P. Chromic Phenomena The Technological Applications of Colour Chemistry, Royal society of Chemistry (RSC), 2001, 374 p.

2. Addington D.M., Schodek D.L. Smart Materials and New Technologies For the architecture and design professions, Elsevier Science, Oxford, 2005, 241 p.

3. Zhao Y., Ikeda T. Smart Light-responsive materials. Azobenze-Containing Polymers and Liquid Crystals, A John Wiley \& Sons, Inc., 2009, 514 p.

4. Granqvist C.G., Green S., Niklasson G.A., Mlyuka N.R., Kraemer S., Georen P. Advances in chromogenic materials and devices, Thin Solid Films, 2010, 518, 3046-3053, doi:10.1016/j.tsf.2009.08.058
5. Pettersson H., Gruszecki T., Johanson L.-H., Edwards M.O.M., Hagteldt A., Matuszczyk T. Direct-driven electrochromic displays based on nanocrystalline electrodes, Displays, 2004, 25, 223-230.

6. Somani P.R., Radhakrishman S. Electrochromic materials and devices: present and future, Materials Chemistry and Physics, 2002, 77, 117-133.

7. Lampert C.M. Large-area smart glass and integrated photovoltaics, Solar Energy Materials \& Solar Cells, 2003, 76, 489-499.

8. Aleksandrova O.A., Bobkov A.A., Maksimov A.I., Moshnikova V.A. et al. Nanostrukturnyye oksidnyye materialy $v$ sovremennoy mikro-, nano $-i$ optoelektronike [Nanostructured oxide materials in modern micro-, nano- and optoelectronics], SPb.: Izd-vo SPbGETU, 2017. 266 p. (Rus)

9. Zhang H., Jeon K.-W., Seo D.-K. Equipment-Free Deposition of Graphene Based Molybdenum Oxide Nanohybrid Langmuir - Blodgett Films for Flexible Electrochromic Panel Application, ACS Applied materials \& interfaces, 2016, 21, 539-544.

10. Palenzuela J., Vinuales A., Odriozola I., Cabanero G., Grande H.J., and Ruiz V. Flexible Viologen Electrochromic Devices with Low Operational Voltages Using Reduced Graphene Oxide Electrodes, ACS Applied materials \& interfaces, 2014, 14, 562-567.

11. Granqvist C. G., Lansaker P. C., Mlyuka N.R., Niklasson G. A., Avendano E., Progress in chromogenics: New results for electrochromic and thermochromic materials and devices. Solar Energy Materials and Solar Cells, 2009. 93, 2032-2039, doi.org/10.1016/j.solmat.2009.02.026

12. Baetens R., Jelle B.P., Gustavsen A. Properties Requirements and Possibilities of Smart Windows for Dynamic Daylight and Solar Energy Control in Buildings: State-of-the-Art. Solar Energy Materials and Solar Cells, 2010, 94(2), 87-105.

13. Granqvist C.G. Transparent conductors as solar energy materials: A panoramic review, Solar Energy Materials and Solar Cells, 2007, 91, 1529-1598.

14. Available at: http://mineralpro.ru/minerals/indium/

15. Indium Tin Oxide and Alternative Transparent Conductor Markets, NanoMarkets study (2009) http://www.criticalrawmaterials.eu/indium-tin-oxide-andalternative-transparent-conductor-markets/ 
16. Dontsova A.Ye., Kalinina A.V. Steklo $s$ upravlyayemoy prozrachnost'yu (smart window) $v$ grazhdanskom stroitel'stve [Glass with controlled transparency (smart window) in civil engineering], Alfabuild, 2018, 4(6), 73-82. (Rus)

17. Novoselov K.S. Nobel Lecture: Graphene: Materials in the Flatland, Reviews of modern physics, 2011, 83, 837-849. doi:10.1103/RevModPhys.83.837

18. Wassei J.K., Kaner R.B. Graphene, a promising transparent conductor, Materials Today, 2010, 13(3), 52-59. https://doi.org/10.1016/S1369-7021(10)70034-1

19. Avouris P. Graphene: Electronic and Photonic Properties and Devices, NanoLetters, 2010, 10, 4285-4294.

20. Moser L.M., Li G., Chen M., Bekyarova E., Mikhail E.I., and Haddon R.C. Fast Electrochromic Devices Based on Single-Walled Carbon Nanotube Thin Films, NanoLetters, 2016, 16(9), 5386-5393. doi: 10.1021/acs.nanolett.6b01564

21. Deb S.K. A Novel Electrophotographic System. Applied Optics, 1969, 8(S1), 192-195 doi.org/10.1364/ AO.8.S1.000192

22. Oksidnyye elektrokhromnyye materialy [Oxide Electrochromic Materials]. Mezhvuz. sb. nauch. trudov, Riga: Latv. gos. un-t im. Petra Stuchki, 1981. (Rus)

23. Faughnan B.W., Crandall R.S., Lampert M.A. Model for the bleaching of $\mathrm{WO}_{3}$ electrochromic films by electric field, Appl. Phys. Lett., 1975, 27(5), 275-277, doi.org/10.1063/1.88464

24. Shtein A.L., Doroshkin A.A., Ulyanova T.V. Sostoyaniye $i$ tendentsii razvitiya passivnykh ploskikh indikatorov [Status and development trends of passive flat indicators]. Foreign electronic technology, 1978, 13, 3-56. (Rus)

25. Svensson J.S.E.M., Granqvist C.G. Electrochromic coatings for "Smart Windows", Solar Energy materials, 1985, 12, 391-402.

26. Granqvist C.G. (Ed.), Handbook of Inorganic Electrochromic Materials, Elsevier Science, Amsterdam, 1995, 1-15, http://dx.doi.org/10.1016/B978-0444899309/50001-5.

27. Monk P.M.S., Mortimer R.J., Rosseinsky D.R. Electrocromism and electrochromic devices, Cambridge university press, 2007, 512 p. doi.org/10.1017/ CBO9780511550959

28. Zhang J.-G., Benson D.K., Tracy C.E., Deb S.K., Czanderna A.W., and Bechinger C. Chromic Mechanism in Amorphous $\mathrm{WO}_{3}$ Films, Journal of the Electrochemical Society 1996, 144(6), 2022-2025.
29. Rauh R.D., Wang F., Reynolds J.R., Mecker D.L. High coloration efficiency electrochromics and their application to multi-color devices, Electrochimica Acta, 2001, 46, 2023-2029.

30. Belousov, A.L., Patrusheva, T.N. Elektrokhromnyye oksidnyye materialy [Electrochromic Oxide Materials], Journal of Siberian Federal University. Enginnering \& Technologies, 2014, 154-166. (Rus)

31. Mortimer R.J. Organic electrochromic materials, Electrochimica Acta 44, 1999, 2971-2981.

32. Rowley N.M., Mortimer R.J. New electrochromic materials, Science Progress, 2002, 85(3), 243-262.

33. Kanagarj M., Velayutham D., Suryanarayanan V., Kathiresan M., and Ho K.-C. Viologen based Electrochromic Materials and Devices, Journal of Materials Chemistry C, 2019, 7(16), 4622-4637.

34. Chudov, K.A., Levchenko, K.S., Poroshin, N.O., Shchegol'kov, A.V., Shmelin, P.S., Grebennikov, Ye.P. Sintez i svoystva novykh elektrokhromnykh proizvodnykh 3aril-4,5-bis (piridin-4-il) izoksazola [Synthesis and Properties of the New Electrochromic Derivatives of 3-aryl4,5-bis (pyridin-4-yl) isoxazole], Izvestiya Akademii nauk. Seriya khimicheskaya. 2019, 8, 1565-1569. (Rus)

35. Zhang G., Lu K., Zhang X., Yuan W., Shi M., Ning H., Tao R., Liu X., Yao R., Peng J. Effects of Annealing Temperature on Optical Films Gap of Sol-gel Tungsten Trioxide Films, Micromachines, 2018, 9(8), 377-386.

36. Louloudakis D., Thongpan W., Mouratis K., Koudoumas E., Kiriakidis G., Singiai P. Novel Spark Method for Deposition of Metal Oxide Thin Films: Deposition o Hexagonal Tungsten Oxide, Physica Status Solidi A, 2019, 216(7), 513-519.

37. Li Y., McMaster W.A., Wei H., Chen D., Caruso R.A. Enhanced Electrochromic Properties of $\mathrm{WO}_{3}$ Nanotreelike Structures Synthesized via a Two-Step Solvothermal Process showing Promise for Electrochromic window Application, ACS Applied Nano Materials, 2018, 1(6), 2552-2558.

38. Availabe at: https://www.oknamedia.ru/novosti/ smart-steklo-novaya-realnost-v-stekolnoy-industrii-45174

39. Harlan J. Byker, Gentex Corporation, "Singlecompartment, self-erasing, solution-phase electrochromic devices, solutions for use therein, and uses thereof, U.S. Patent No. 4, 902, 108 (1990).

40. Heckner K.-H., Kraft A. Similarities between electrochromic windows and thin film batteries. Solid State Ionics, 2002, 899-905. 